\title{
Resenha
}

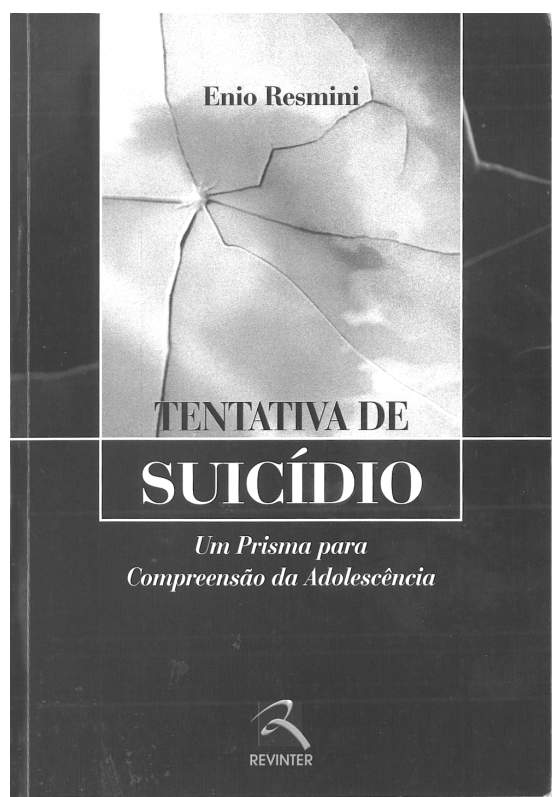

O autor apresenta, com uma linguagem clara e objetiva, a questão das ideações, tentativas e do suicídio propriamente dito, especialmente na adolescência, faixa etária em que esta é a segunda ou terceira causa mortis, dependendo do local da pesquisa e da metodologia utilizada.

"Na Europa, as principais causas de óbito entre os 15-35 anos, em ordem decrescente, são: acidentes de trânsito, suicídio e câncer", informa Resmini. Já em nosso país, mais da metade das pessoas que tentam o suicídio não procuram nem são levados à assistência médica. Segundo o autor, seriam $53,3 \%$, porém é provável que este número seja muito maior, haja vista que os estudos epidemiológicos brasileiros relacionados ao suicídio são isolados e restritos mais às Regiões Sul e Sudeste do país. Além disso, os dados são, muitas vezes, omitidos devido às "exigências" de vários convênios médicos de saúde, que não remuneram o tratamento profissional nem hospitalar quando se relata na ficha do paciente
* Resmini E. Tentativa de suicídio - um prisma para compreensão da adolescência. Rio de Janeiro: Revinter; 2004.

**Psiquiatra, Doutor em Saúde Mental (Unicamp), Pós-Doutor e Professor da Faculdade de Medicina de Lisboa, Professor da Universidade Católica Dom Bosco, Campo Grande, MS.

\section{Resenha do livro Tentativa de suicídio - um prisma para compreensão da adolescência, de Enio Resmini*}

\author{
José Carlos Souza**
}

o termo "suicídio"; há, inclusive, um grande estigma em relação ao suicídio entre os próprios profissionais de saúde, como se não bastasse a restrição brutal das empresas de seguros de vida, que o "abominam".

O autor do livro apresenta uma visão multi- e transdisciplinar do suicídio, o que facilita a sociabilização dos conhecimentos para os leigos no assunto. Inicialmente, na Parte I, o autor aborda o que muitos chamam de "síndrome normal da adolescência"; em seguida, os aspectos psicopatológicos do adolescente. Neste segundo capítulo, o autor poderia ter aprofundado mais a visão das diversas escolas psicopatológicas sobre as doenças e os sintomas mentais, porém, talvez, este não tenha sido o propósito principal do livro.

Na Parte II, há a conceituação de suicídio, dados estatísticos sociodemográficos, fatores de risco e protetores contra o ato suicida, além dos modelos teóricos de compreensão do comportamento e da tendência ao suicídio. Neste último, chama a atenção a valiosa visão holística do autor em relação ao ser humano.

$\mathrm{Na}$ Parte III, sobre a abordagem e o manejo das ideações e tentativas de suicídio, há sete capítulos bem condensados, que podem auxiliar bastante tanto generalistas como especialistas da área. No antepenúltimo 
capítulo do livro, a contratransferência é abordada de uma maneira aprofundada e, ao mesmo tempo, de fácil compreensão. Como é referido por Chiles \& Strosahl (1995), "os aspectos mais difíceis no trabalho com os suicidas são as reações dentro do entrevistador", principalmente quando se leva em consideração a notoriedade de que o ser humano, dependendo das circunstâncias e do momento de sua vida, estará disposto a falar a verdade sobre si, a amenizá-la, exagerá-la ou omiti-la. Este fato desencadeia sentimentos conscientes e inconscientes no profissional que trabalha com 0 paciente suicida, em especial quando o auto-aniquilamento é concretizado. Lembra-se, aqui, que o profissional é um ser humano, tanto quanto o seu cliente, mesmo que, muitas vezes, em seu curso de graduação universitária, tenha sido "embutida" a ele uma sobrecarga de onipotência e, por que não dizer, de "onisciência". Em se tratando do paciente suicida, não há como se afirmar, com certeza, se o rumo está correto ou não; nessa área, infelizmente, uma terapêutica aparentemente adequada pode significar apenas uma dose de alívio da ansiedade do profissional.

Em se tratando de terapêuticas, o autor, no último capítulo do livro, deixa a desejar quando se refere à eletroconvulsoterapia (ECT) em apenas três linhas, quando esta, muitas vezes, pode ser o tratamento de primeira escolha em situações de emergência. Neste capítulo, o autor pode frustrar o leitor, pois cita a ECT no título e se ocupa dela somente nas últimas três linhas do livro.

Contudo, o Dr. Enio Resmini brinda a literatura científica da área com esta contribuição.

Title: Book review: Tentativa de suicídio - um prisma para compreensão da adolescência, by Enio Resmini

Título: Reseña del libro Tentativa de suicídio - um prisma para compreensão da adolescência, de Enio Resmini

Copyright (C) Revista de Psiquiatria do Rio Grande do Sul - SPRS 